\title{
DJERFISHERITE IN KIMBERLITE-HOSTED MANTLE XENOLITHS: TEXTURAL FEATURES, COMPOSITION AND ORIGIN
}

\author{
I.S. Sharygin, A.V. Golovin, N.P. Pokhilenko \\ V.S.Sobolev Institute of Geology and Mineralogy SB RAS, Koptyuga pr. 3, Novosibirsk 630090, Russia
}

\section{INTRODUCTION}

Djerfisherite (ideally, $\mathrm{K}_{6} \mathrm{Na}(\mathrm{Fe}, \mathrm{Ni}, \mathrm{Cu})_{24} \mathrm{~S}_{26} \mathrm{Cl}$ ) is widespread in kimberlite-hosted xenoliths and diamonds. It usually occurs as rims around primary $\mathrm{Fe}-\mathrm{Ni}-\mathrm{Cu}$ sulfides. It is assumed that metasomatic origin of djerfisherite is due to interaction of primary sulfides with the hypothetical K-Clrich fluid or melt (e.g., Bulanova et al, 1990). However, source of metasomatizing agent and PT-conditions of this interaction is unclear. Djerfisherite also was found in the groundmass of kimberlites from Siberian (Russia) (e.g., Sharygin et al., 2007, 2008) and Slave (Canada) (e.g., Clark et al., 1994) cratons among primary magmatic phases of late stages of crystallization. Examination of literature data on mantle xenoliths from different sources, such as alkaline basalts and kimberlites, shows that djerfisherite is observed only in kimberlite-hosted mantle xenoliths. Here we present the detailed study of djerfisherite from the deepest mantle xenoliths - sheared peridotites from kimberlites of Udachnaya-East pipe (Siberian craton, Russia) and compare them with those in other mantle xenoliths and in groundmass of host rocks.

\section{SAMPLE DESCRIPTION}

We have studied 25 unaltered sheared peridotite xenoliths (Fig. 1) from uniquely fresh kimberlite of the Udachnaya-East pipe, which were firstly unsealed in 2001. The sheared xenoliths show porphyroclastic to fluidalmosaic-porphyroclastic textures (based on the classification of Harte, 1977). The rock-forming (primary) mineral assemblage of these xenoliths is composed of olivine, garnet \pm orthopyroxene \pm clinopyroxene. The P-T conditions of formation for these paragenesis, based on geothermobarometer of (Brey, Köhler, 1990), can be estimated as $\mathrm{P}=60-73 \mathrm{~kb}$ and $\mathrm{T}=1230-1370{ }^{\circ} \mathrm{C}$.

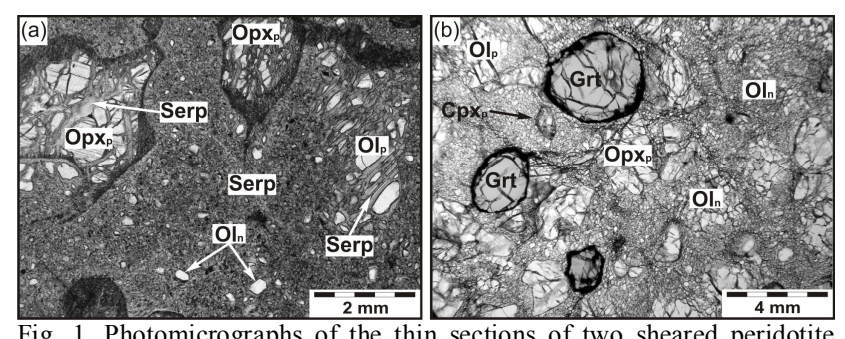

Fig. 1. Photomicrographs of the thin sections of two sheared peridotite xenoliths with mosaic-porphiroclastic texture from Udachnaya-East pipe. a) Sample UV-7/85 collected in 1985 with serpentinized olivine neoblasts (almost completely) and olivine and ortopyroxene porphiroclasts (along fractures); Sample UV-3/05 collected in 2005 with fresh olivine both neoblasts and porphiroclasts. Grt - garnet, $\mathrm{Ol}_{\mathrm{p}}$ - olivine porphiroclast, $\mathrm{Ol}_{\mathrm{n}}$ olivine neoblast; $\mathrm{Opx}_{\mathrm{p}}-$ orthopyroxene porphiroclast, $\mathrm{Cpx}_{\mathrm{p}}-$ clinopyroxene porphiroclast, Serp - serpentine.

\section{ANALYTICAL METHODS}

Thin sections were studied using Olympus BX51 microscope with Olympus COLOR VIEW III camera. The chemical composition of djerfisherite was determined on CAMEBAX and JEOL JXA-8100 electron microprobes at the V.S. Sobolev Institute of Geology and Mineralogy SB RAS (Novosibirsk, Russia) using standard techniques. EDS spectra, BSE images and X-ray elemental mapping were carried out using a LEO electron scanning microscope coupled with dispersive X-ray microanalysis system INCA Energy 350 (Oxford Instruments) at the IGM SB RAS.

\section{RESULTS}

Djerfisherite is the dominant sulfide phase in studied xenoliths. Basically four types of djerfisherite can be defined in sheared peridotite xenoliths based on texture, size and location within xenoliths. 


\section{$10^{\text {th }}$ International Kimberlite Conference, Bangalore - 2012}

Type-1 djerfisherite (Dj-1) rims primary $\mathrm{Fe}-\mathrm{Ni}-\mathrm{Cu}$ sulfides (pyrrhotite + pentlandite + chalcopyrite) which form blebs enclosed in rock-forming minerals (Fig. 2). Blebs containing djerfisherite communicate with the grain boundary of host silicates by secondary fractures (Fig. 2 a, b). Isolated blebs consist only of Fe-Ni-Cu sulfides (Fig. 2 c, d). These facts suggest that $\mathbf{D j} \mathbf{j - 1}$ is secondary mineral in sulfide blebs. The relationship of minerals in the blebs shows that djerfisherite replaced $\mathrm{Fe}-\mathrm{Ni}-\mathrm{Cu}-\mathrm{sulfides}$. The composition of $\mathbf{D j - 1}$ varies within the following ranges (in wt.\%): Fe 34.8-45.3; Ni 7.7-19.5; Co up to 0.6; Cu 0.1-6.3.
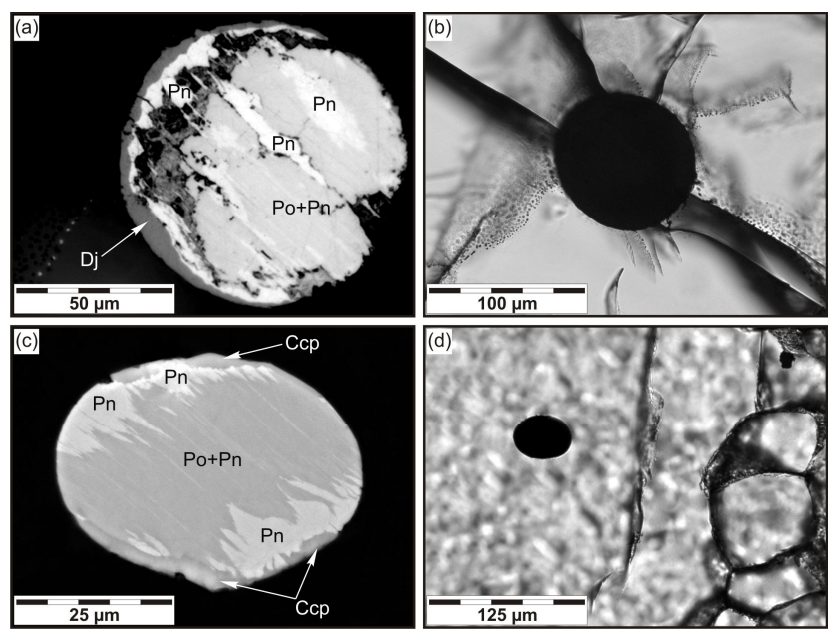

Fig.2. Sulfide blebs from primary silicates of xenoliths. a, b) Sulfide bleb containing djerfisherite. b) Isolated sulfide bleb. a - reflected light, c BSE image, b, d - ordinary light. $\mathrm{Dj}$ - djerfisherite, Po - pyrrhotite, Pn pentlandite, Ccp- chalcopyrite.

Type-2 djerfisherite ( $\mathrm{Dj}-2)$ forms rims around large interstitial segregations of primary Fe-Ni sulfides (up to 300 $\mu \mathrm{m})$ (Fig. 3). $\mathbf{D j}-\mathbf{2}$ is secondary to this assemblage. The composition of $\mathbf{D j} \mathbf{- 2}$ is (in wt.\%): Fe 37.5-44.9; Ni 8.016.9; Co up to $0.4 ; \mathrm{Cu}$ 0.4-7.0.
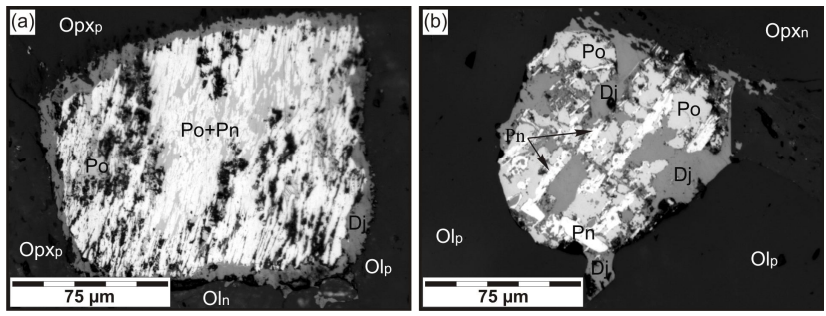

Fig. 3. Large interstitial sulfide segregations with type-2 djerfisherite. Reflected light.
Type-3 djerfisherite ( $\mathrm{Dj}-3$ ) occurs as individual (up to up to $50 \mu \mathrm{m}$ ) euhedral and subhedral (rarely xenomorphic) grains in interstitial assemblage which not related to large Fe-Ni sulfide masses (Fig. 4). Other minerals of interstitial assemblage are represented by olivine, monticellite, clinopyroxene, phlogopite, tetraferriphlogopite, zoned spinel (chromite, Ti-magnetite, magnetite), perovskite, apatite, calcium carbonate (calcite and aragonite) and sulfides (monosulfide solid solution, pentlandite, pyrrhotite and djerfisherite). The composition of $\mathbf{D j - 3}$ varies within the following ranges (in wt.\%): $\mathrm{Cu} 0.1-10.2$; Fe 39.7-47.4; $\mathrm{Ni} 4.5-12.2$; Со до 0.9.
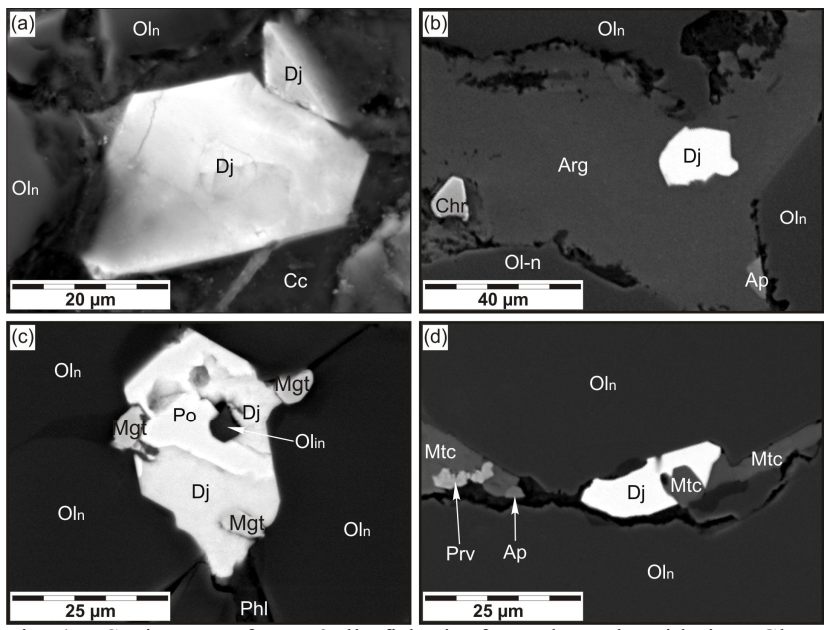

Fig. 4. BSE images of type-3 djerfisherite from sheared peridotites. $\mathrm{Chr}$ chromite, Mgt - magnetite, $\mathrm{Chr}$ - chromite, $\mathrm{Prv}$ - perovskite, $\mathrm{Cc}$ - calcium carbonate, Arg - aragonite, Ap - apatite, Phl - phlogopite, Mtc monticellite, $\mathrm{Ol}_{\text {in }}$ - interstitial olivine.

Type-4 djerfisherite (Dj-4) is present as daughter phase in melt inclusions in primary silicates of peridotites (Fig. 5). See detailed study of these inclusions in Golovin et al. (this volume). Melt inclusions occur as clusters in differently oriented healed cracks (Fig. 5), and hence, can be considered as secondary melt inclusions. They consist of fine-grained aggregate of carbonates, sulphates and chlorides, some translucent crystals (olivine, clinopyroxene, phlogopite, tetraferriphlogopite, apatite, perovskite, halite, sylvite, various carbonates and sulfates), opaque minerals (magnetite and sulfides) and a bubble. Various carbonates and sulfates were recognized via the laser Raman spectroscopy (Golovin et al., this volume). In general the main phases are $\mathrm{Ca}-, \mathrm{Na}-$ and K-bearing carbonates, chlorides and sulphates, whereas silicate minerals occupy $<15$ vol. $\%$ of the inclusion volume. Thus, these inclusions have composition close to alkaline-carbonatite magmas. Sulfide assemblage of melt inclusions is represented by pentlandite, pirrhotite, djerfisherite and $\mathrm{Cl}$-free $\mathrm{K}-\mathrm{Fe}$ sulfide. Dj-4 has the following compositional variations (in wt.\%): Fe 38.6-47.9; Ni 4.2-14.6; Co up to 0.3; $\mathrm{Cu}$ 0.1-10.3. 


\section{$10^{\text {th }}$ International Kimberlite Conference, Bangalore - 2012}
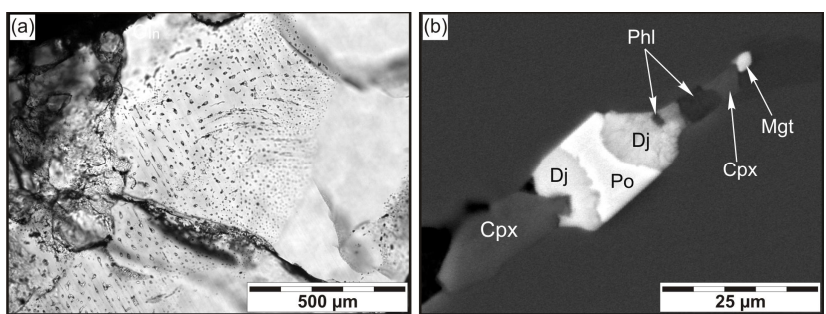

Fig. 5. Photomicrograph of secondary melt inclusions in olivine from sheared peridotite xenoliths from Udachnaya-East pipe. a) Melt inclusions cluster. Ordinary light. b) BSE image of individual melt inclusion containing sulphide minerals. $\mathrm{Cpx}$ - clinopyroxene

\section{DISCUSSIONS}

\section{Origin of djerfisherite}

Djerfisherite from studied samples is characterized by various textural features and composition. Its relation to other minerals of xenoliths indicates that all types of djerfisherite crystallized after rock deformation and recrystallization. Recrystallization of sheared peridotites occurred shortly before they were entrainment in host magma (for example, see review in Pearson et al., 2003). Mineralogy of the interstitial assemblages in studied xenoliths, excepting some minerals, resembles that of the kimberlites from the Udachnaya-East pipe (Kamenetsky et al., 2004; Golovin et al., 2007; Sharygin et al., 2007). Compositions of most interstitial and groundmass minerals are identical (Kamenetsky et al., 2004; Golovin et al., 2007; Sharygin et al., 2007). The daughter phase mineralogy of secondary melt inclusions in sheared peridotites similar to that of the melt inclusion in olivine phenocrysts from unaltered kimberlites of Udachnaya-East pipe (Golovin et al., 2007). These facts suggest that origin of djerfisherite in sheared peridotite xenoliths from Udachnaya-East pipe and xenoliths worldwide can be explained by infiltration of the host kimberlitic melt and its reactions with primary assemblage of xenoliths (Sharygin et al, 2012). Type-3 and type-4 djerfisherite compositions are similar to those from kimberlite groundmass of the Udachnaya-East pipe (Fig. 6). Type- 1 and type- 2 djerfisherites are characterized by higher $\mathrm{Ni}$ content (Fig. 6) and close to djerfisherite from diamonds. Djerfisherite mostly replaces pentlandite because of similarity of their crystal structures and it explains high $\mathrm{Ni}$ in djerfisherite rimming primary $\mathrm{Fe}-\mathrm{Ni}-\mathrm{Cu}$ sulfide. Thus, djerfisherite forming individual grains in melt inclusions and interstitial assemblages crystallized directly from infiltrating kimberlitic melt. Djerfisherite rimming primary sulfides is a product of reaction of infiltrating kimberlitic melt and primary sulfides.

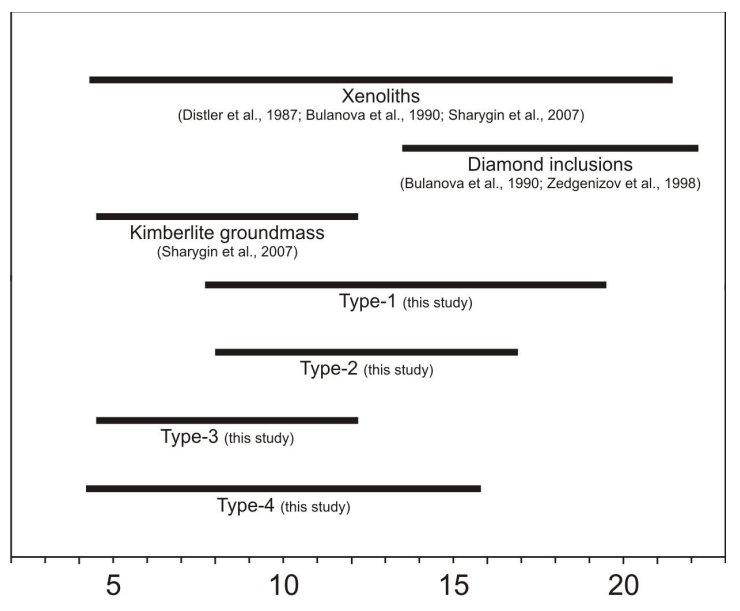

$\mathrm{Ni}$ in djerfisheriete (wt.\%)

Fig. 6. The Ni concentrations range of different types of djerfisherite from studied samples, djerfisherite from Udahnaya-East kimberlite groundmass, djerfisherite from Siberian mantle-derived xenoliths and diamonds.

\section{Implications}

During the last decade the role of chlorine in kimberlite magma has been widely discussed (Kamenetsky et al., 2007, 2008, 2009). The Udachnaya-East pipe presents an only example of exceptionally fresh kimberlitic rocks with very low water $(<0.5$ wt.\%) and high chlorine (up to 6 wt.\%) contents (Kamenetsky et al., 2007, 2008, 2009). This enrichment of chlorine is defined by presence of abundant chlorine-bearing minerals such as halite, sylvite, sodalite, and djerfisherite. With the exception of djerfisherite these minerals were never been found in other kimberlites. Thus, halite, sylvite, sodalite (and as a result - high chlorine content) cannot survive during post-magmatic alteration of kimberlites. The presence of djerfisherite in kimberlites can be used as the evidence for former enrichment of altered rocks by chlorine. It should be noted that, however, djerfisherite in kimberlite groundmass occurs less frequently then in mantle xenoliths. According to our results we can suggest that the presence of djerfisherite in xenoliths also indicate enrichment of kimberlitic magma by chlorine (Sharygin et al, 2011, 2012). At present djerfisherite was discovered at least in 11 kimberlite pipes in Eastern Siberia (Russia) (Fig. 7), as well in pipes of Northwest Territories (Canada) (e.g., Clark et al., 1994), and Northern Cape Province (South Africa) (Clark et al., 1977). Thus, widespread occurrence of djerfisherite in kimberlites and their mantle xenoliths may indicate that role of chlorine in kimberlite magmatism was underestimated. 


\section{$10^{\text {th }}$ International Kimberlite Conference, Bangalore - 2012}

Presence of djerfisherite in xenoliths and groundmass of kimberlites from pipes of Kuoika field (western surrounding of the Olenek uplift) (Fig. 7), for which assimilation of saline deposits or interaction with brines are excluded, can be considered as an unambiguous argument supporting the mantle nature of chlorine in kimberlite melts (Sharygin et al, 2011). Pipes of the Kuoika field at the modern erosion level are localized in Precambrian and Lower Cambrian rocks do not contain saline deposits (Fig. 7). Middle Cambrian, Permian, Triassic, and Jurassic rocks were there at the moment of kimberlite eruption. This is evident from datings of xenogenic sedimentary material, as well as reconstructed epochs of denudation and sedimentation at the Siberian platform. Proterozoic and Cambrian saline deposits are absent in the area of the Olenek uplift and at the neighboring territories, whereas saline deposits were not registered in Permian and Mesozoic series on the whole territory of the Siberian platform. In addition, these pipes are located outside the area of abundance of brines (Fig. 7).

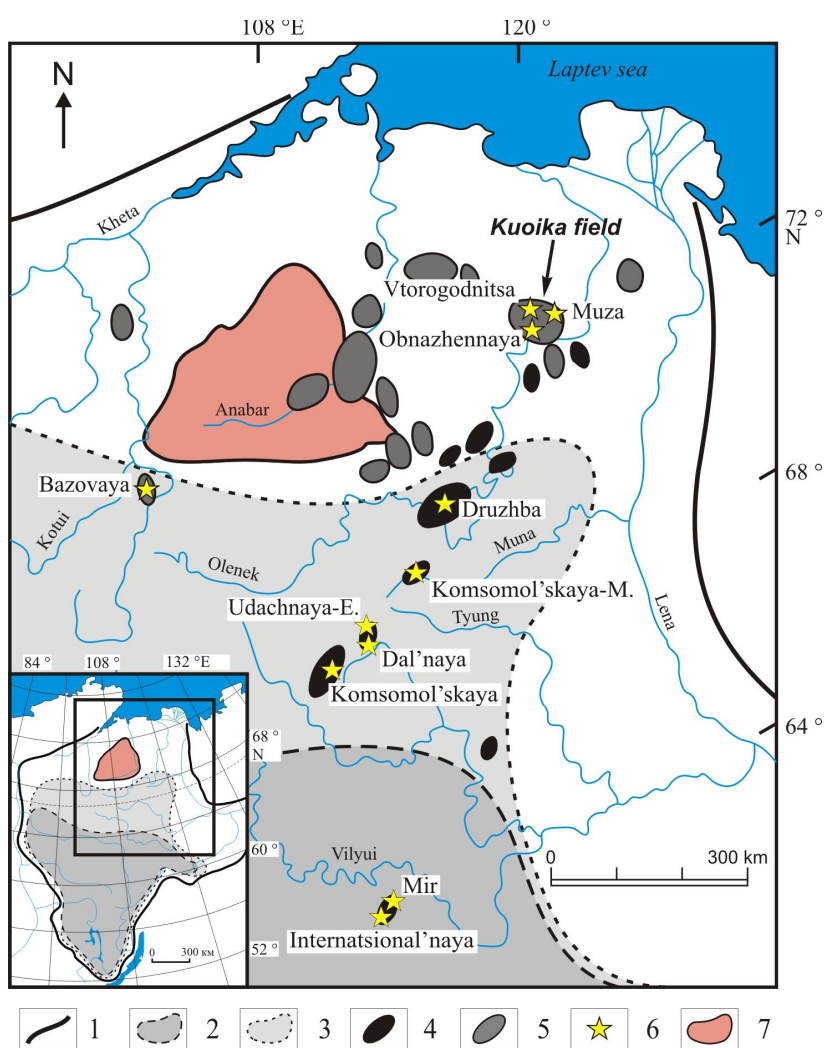

Fig. Sketch map of location of kimberlitic fields on the Siberian platform and contours of saline Cambrian deposits and modern brines. (1) Boundaries of the Siberian platform; $(2,3)$ areas of Cambrian saline deposits (2) and complete abundance of brines; $(4,5)$ fields of kimberlites of Paleozoic (4) and Mesozoic (5) ages; (6) kimberlitic pipes with djerfisherite in kimberlites and/or mantle xenoliths; (7) Anabar shield.
The presence of djerfisherite and other secondary accessory minerals can significantly affect the whole-rock chemical characteristics of the xenoliths, which are used to reconstruct the processes of transformation of mantle rocks. For example, bulk concentrations of $\mathrm{K}_{2} \mathrm{O}$ in the sheared peridotites are 0.2-0.3 wt.\%. Only clinopyroxene is $\mathrm{K}$ bearing among primary minerals. $\mathrm{K}_{2} \mathrm{O}$ content in clinopyroxene from the studied xenoliths does not exceed 0.07 wt.\%. Simple calculation shows that even at the maximum for the sheared peridotites clinopyroxene content (ca. 20 vol.\%), this mineral cannot compensate bulk concentration of $\mathrm{K}_{2} \mathrm{O}$. Djerfisherite and micas are the main storages for potassium in studied peridotites.

\section{CONCLUSIONS}

1) Origin of djerfisherite in sheared peridotite xenoliths from Udachnaya-East pipe as well as in oher xenoliths and diamonds is result of infiltration of the host kimberlitic melt and its reactions with primary xenolith minerals. Djerfisherite forming individual grains in melt inclusions and interstitial assemblages crystallized directly from infiltrating kimberlitic melt. Djerfisherite rimming primary sulfides is a product of reaction of infiltrating kimberlitic melt and primary sulfides.

2) Thus, the presence of djerfisherite in multi-age kimberlite pipes worldwide supports the idea about significant chlorine concentrations in kimberlites, and this element should be an important component in other kimberlites rather than at the Udachnaya-East pipe only.

3) Findings of djerfisherite in pipes of Kuoika field, for which assimilation of saline deposits or interaction with brines are excluded, can be considered as an unambiguous argument supporting the mantle nature of chlorine in kimberlitic melts.

4) The presence of djerfisherite and other secondary accessory minerals can significantly affect the whole-rock chemical characteristics of the xenoliths, which are used to reconstruct the processes of transformation of mantle rocks.

This work was supported by the Russian Foundation of Basic Research (grant No. 10-05-00575-a) and IGM SB RAS (grant No. VMTK-13).

\section{References}

Brey, G.P., Köhler, T. (1990) Geothermobarometry in four phase lherzolites II. New thermobarometers, and practical assessment of using thermobarometers. J. Petrol., v. 31, part 6, pp. 1353-1378.

Bulanova, G.P., Spetsius, Z.V., Leskova, N.V. (1990) Sulfides in diamonds and xenoliths from kimberlitic pipes of Yakutia. Nauka, Novosibirsk, 120 pp. (in Russian).

Clarke, D.B., Pe, G.G., MacKay, R.M., Gill, K.R., O’Hara, M.J. Gard, J.A. (1977) A new potassium-iron-nickel sulfide from a nodule in kimberlite // Earth Planet. Sci. Lett., v. 35, pp. 421-428. 


\section{$10^{\text {th }}$ International Kimberlite Conference, Bangalore - 2012}

Clarke, D.B., Mitchell, R.H., Chapman, C.A.T., MacKay, R.M. (1994) Occurrence and origin of djerfisherite from the Elwin Bay kimberlite, Somerset Island, Northwest Territories.// Can. Mineral., v. 32, No 4, pp. 815-823.

Distler, V.V., Ilupin, I.P., Laputina, I.P. (1987) Sulfides of deep-seated origin in kimberlites and some aspects of copper-nickel mineralization // Int. Geol. Review, v. 29. pp. 456-464.

Golovin, A.V., Sharygin, V.V., Pokhilenko, N.P. (2007) Melt inclusions in olivine phenocrysts in unaltered kimberlites from the Udachnaya-East pipe, Yakutia: some aspects of kimberlite magma evolution during late crystallization stages. Petrology, v. 15, pp. 168-183.

Harte, B. (1977) Rock nomenclature with particular relation to deformation and recrystallisation textures in olivine-bearing xenoliths. J. Geol., v. 85, pp. 279-288

Kamenetsky, M.B., Sobolev, A.V., Kamenetsky, V.S., Maas, R., Danyushevsky, L.V., Thomas, R., Sobolev, N.V., Pokhilenko, N.P. (2004) Kimberlite melts rich in alkali chlorides and carbonates: a potent metasomatic agent in the mantle. Geology, v. 32, pp. 845-848.

Kamenetsky, V.S., Kamenetsky, M.B., Sharygin, V.V., Golovin, A.V. (2007) Carbonate-chloride enrichment in fresh kimberlites of the Udachnaya-East pipe, Siberia: a clue to physical properties of kimberlite magmas? Geophys. Res. Lett., v. 34, pp. 9316-9321.

Kamenetsky, V.S., Kamenetsky, M.B., Sobolev, A.V., Golovin, A.V., Demouchy, S., Faure, K., Sharygin, V.V., Kuzmin, D.V. (2008) Olivine in the Udachnaya-East kimberlite (Yakutia, Russia): types, compositions and origins. J. Petrol., v. 49, pp. 823-839.

Kamenetsky, V.S., Maas, R., Kamenetsky, M.B., Paton, C., Phillips, D., Golovin, A.V., Gornova, M.A. (2009) Chlorine from the mantle: Magmatic halides in the Udachnaya-East kimberlite, Siberia. Earth Planet. Sci. Lett., v. 285, pp. 96-104.

Pearson, D.G., Canil, D., Shirey, S.B. (2003) Mantle samples included in volcanic rocks: xenoliths and diamonds. in Treatise on geochemistry, $\mathrm{v}$. 2, Geochemistry of the mantle and core, pp. 171-275.

Sharygin, V.V., Golovin, A.V., Pokhilenko, N.P., Kamenetsky, V.S. (2007) Djerfisherite in the Udachnaya-East pipe kimberlites (SakhaYakutia, Russia): paragenesis, composition and origin. Eur. J. Miner., v. 19, pp. 51-63.

Sharygin, V.V., Kamenetsky, V.S., Kamenetsky, M.B. (2008) Potassium sulfides in kimberlite-hosted chloride-"nyerereite" and chloride clasts of Udachnaya-East pipe, Yakutia, Russia. Can. Mineral. v. 46, pp. 10791095.

Sharygin, I.S., Golovin, A.V., Pokhilenko, N.P. (2011) Djerfisherite in kimberlites of the Kuoikskoe field as an indicator of enrichment of kimberlite melts in chlorine. Dokl. Earth Sci. v. 436, part 2, pp. 301307

Sharygin, I.S., Golovin, A.V., Pokhilenko, N.P. (2012) Djerfisherite in sheared peridotite xenoliths from Udachnaya-East pipe (Yakutia): origin and its relation to kimberlite magmatism. Russ. Geol. Geophys., in press.

Zedgenizov, D.A., Logvinova, A.M., Shatskii, V.S., Sobolev, N.V., Inclusions in microdiamonds of some kimberlite pipes of Yakutia. Dokl. Earth Sci. v. 339, part 1, pp. 74-78. 